\title{
Professor Ramón Llamas: a founding father of hydrogeology in Spain
}

\author{
P. Martínez-Santos ${ }^{1} \&$ F. Villarroya ${ }^{1}$
}

Keywords Profile (of eminent hydrogeologist) · Spain • Socio-economic aspects $\cdot$ Semiarid regions

\section{Biographical sketch}

Manuel Ramón Llamas Madurga was born in Valladolid, Spain, on October 3, 1931. At the time, his father, a civil engineer, was the director of the recently established Douro River Basin Authority. Following in his footsteps, Ramón completed his civil engineering degree at the Universidad Politécnica de Madrid, Spain, in 1956. A keen interest in the Earth sciences led him to enroll simultaneously in a geology degree at the Universidad Complutense de Madrid, which he finished two years later. By 1963 he had already completed his two PhDs.

He joined the Civil Engineer Corps, serving at the Eastern Pyrenees Basin Authority (1959-1960), the Geological Survey of Public Works (1960-1972) and the Center of Studies for Land and Environmental Management of the Ministry of Public Works (1980-1982). The Ministry allowed him to further his professional specialization in France (1963), Germany (1964) and Israel (1965).

Early on, his work delved into conventional hydraulics and engineering geology; however, the focus soon shifted to water planning and, thus, Dr. Llamas became a pioneer in the study of Spain's aquifers. His research emphasized the evaluation,

\footnotetext{
* P.Martínez-Santos pemartin@ucm.es

${ }^{1}$ Departamento de Geodinámica, Facultad de Ciencias Geológicas, Universidad Complutense de Madrid, C/José Antonio Novais 12, 28040 Madrid, Spain
}

development and management of groundwater resources. During his time at the national administration he co-authored over 100 official reports on water resources, geotechnical engineering and environmental characterization and protection.

Despite his professional affiliation, Dr. Llamas remained close to the academic world. Around the mid-1960s, he was

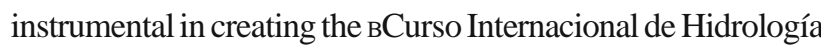
Subterránea^ (вInternational Groundwater Hydrology Course ${ }^{\wedge}$ ) of the Universidad Politécnica de Cataluña, Spain.

The course soon became a reference for hydrogeologists around the world, particularly in Spanish-speaking countries. In early 2016, the course celebrated its 50th edition, which makes it the longest-standing postgraduate course of all Spanish universities.

Dr. Llamas joined the academia as a full-time lecturer in 1972. He worked for different institutions, including the Universidad Central de Barcelona, the Universidad Politécnica de Cataluña and the Universidad Autónoma de Madrid. He was also appointed professor of the Manhattan College, New York (USA), in 1978; however, he spent most of his academic life at the Universidad Complutense de Madrid, where he held different posts for two periods of time (1972-1978 and 1985-2002) over 23 years. He taught geology, hydrology, hydrogeology, hydrogeochemistry and applied statistics courses until 2002, when he became professor emeritus.

\section{Scientific and human legacy}

Professor Llamas is author or co-author of nearly 100 books and about 400 scientific papers. Between the early 1970s and the mid-1990s, his research focused on hydrogeology in the conventional sense. During this time he led the early work on 
some of Spain's most important aquifer systems, while also playing a relevant role in the water policy arena.

He actively partook in bringing in new researchers, to the point that many of Spain's current hydrogeology professors have been his graduate students or his co-workers. Together with Professor Emilio Custodio, Professor Llamas edited the world-famous textbook вHidrología subterránea^ (BGroundwater hydrology^), a two-volume 2,400-page treatise which is often referred to as sthe Bible of Hydrogeology in Spanish^ (Custodio and Llamas 1976). The book contains a number of chapters that hint at one of the key aspects of Prof. Llamas' legacy: his holistic view of groundwater resources. Indeed, Professor Llamas understood the multidimensional nature of water and the unique challenges of groundwater governance from the very outset (Llamas and MartínezSantos 2005; Llamas et al. 2006a, b). He produced a number of thought-provoking and challenging policy papers on the social and economic value of groundwater in semi-arid terrains, guest editing a special issue of Hydrogeology Journal on this very topic (Llamas et al. 2006b). Practical experience led him to advocate interdisciplinary dialogue as a means to deal with the complexities of managing groundwater resources; thus, he assembled a stable crew of professionals from different fields, including hydrologists, geologists, economists, sociologists, geographers, lawyers and environmental scientists, as well as civil, agricultural and mechanical engineers.

Within this context, Professor Llamas designed and directed a large research program (with a total duration of nearly 5 years and a budget in excess of one million euro), on the role of groundwater resources in water policy. The project was funded by the Botín Foundation, and became the seed of the Water Observatory, which was formally established in 2008. The Water Observatory was founded to provide innovative solutions to water management problems, adopting a holistic approach to address the various aspects of water governance and integrated water resources management.

The association with the Botín Foundation came at a moment when Professor Llamas' academic duties were coming to an end; thus, it delivered a timely alternative for his research to continue. At first, it provided an outlet for the publication of many reference works on groundwater management (Llamas et al. 2001; Llamas and Custodio 2003; Coleto et al. 2003). Later on, it contributed to broaden the scope to fields such as water and food security (Martínez-Cortina et al. 2010; Garrido et al. 2010; Willaarts et al. 2014), integrated water resources management (Rogers et al. 2006; De Stefano and Llamas 2013; Martínez-Santos et al. 2014) or water ethics (Llamas et al. 2009), but most importantly, the Water Observatory became an influential think-tank, both in Spain and abroad. Its international seminars soon turned into a trademark approach to water research, based on open-minded debates among some of the world's foremost academics and authorities. Ramon
Llamas stood down as Director of the Water Observatory in 2016, only to be appointed director emeritus.

\section{Distinctions, prizes and accolades}

Professor Llamas received numerous distinctions along his career. He was elected a member of Spain's Royal Academy of Sciences in 1986 (Fig. 1), where he stressed the importance of hydrogeology in his inaugural speech (BGroundwater as an ecological and economic resource and as a geological agent $\wedge$ ). He chaired the Section of Natural Sciences between 2000 and 2008 and the International Relations Committee from 2003 to 2013.

In the early 1990s, he was commissioned by the French municipality of Murviel-lès-Montpellier to carry out a study on the environmental impact of a projected landfill. In recognition to his work, the city council awarded him the Citoyen d'Honneur distinction in 1992.

Prof. Llamas was president of the International Association of Hydrogeologists (IAH) from 1984 to 1989. He was instrumental in initiating a sponsored membership scheme within IAH, which was one of the first such schemes established by a professional association, enabling central funds to be used to support colleagues from developing nations (Struckmeier et al. 2016). A notable contribution to Hydrogeology Journal, entitled BThe role of the Spanish Committee of the International Association of Hydrogeologists in the management and protection of Spain's groundwater resources $\wedge$ (Custodio et al. 1998), exemplifies his ability to encourage involvement. He was also vice-president of the International Association of Water Resources from 2001 to 2003.

Prof. Llamas made his religious faith the cornerstone of his daily life. Largely as a result, he showed a keen interest in water ethics, coordinating UNESCO's working group on the ethics of the use of freshwater resources (1998-1999). Genuinely concerned about the wellbeing of all humans, he was also involved with different charities; thus, he became the co-founder of CODESPA, a private foundation that promotes

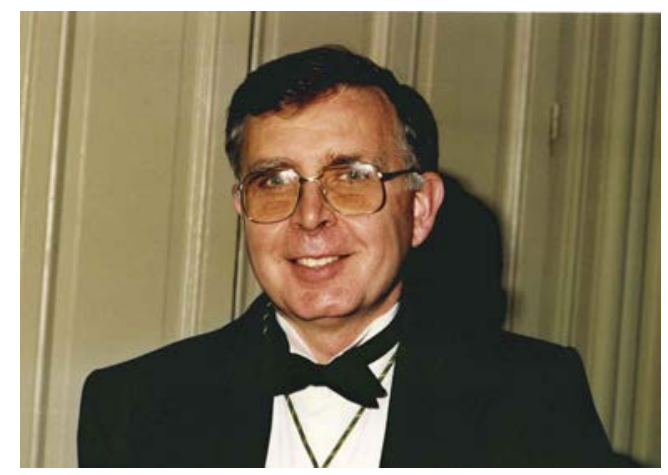

Fig 1 Prof. Ramón Llamas on the day he was appointed a member of Spain's Royal Academy of Sciences (April 1988) 


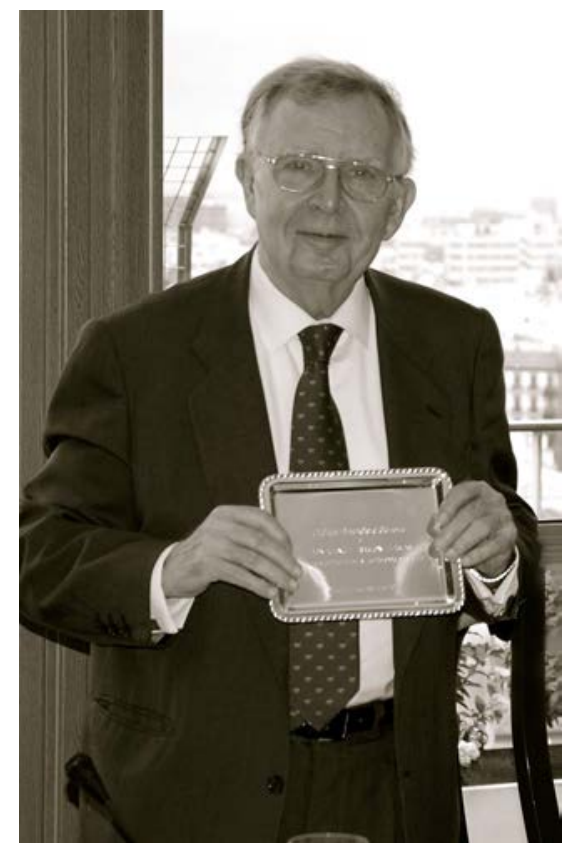

Fig 2 Prof. Ramón Llamas at an event at the вClub Financiero Génova^, Madrid, in 2010

human development in low-income countries (1996-1998), as well as a member of the Technical Scientific Committee of Action Against Hunger (1999-2004).

Prof. Llamas was appointed as an honorary member of the Geological Society of the United Kingdom (1994), an advisor to the American Institute of Hydrology (1998), and a member of the Water Commission of the Word Humanity Action Trust (1998). He is also an honorary member of the IAH (2002), a fellow of the European Academy of Science and Arts (2005), a member of the French Academie de l'Eau (2006) and a fellow of the Spanish Royal Academy of Doctors (2008). He was a member of the Management Board of Las Tablas de Daimiel and Doñana National Parks between 1996 and 1999.

He has received numerous prizes and accolades (Fig. 2). He won the Scientific Outreach Award of Spain's BClub de la Energía^ in 1995. He also received the Honoris Causa distinction of the Universidade da Coruña and Universidad Politécnica de Cataluña in 2002 and 2010, respectively, and the Life Member Award of the National Ground Water Association in 2003. In 2006 he was awarded the International Cannes Prize for Water.

\section{Final remarks}

Professor Ramón Llamas' outstanding career represents a milestone in hydrogeology. His work has contributed to shape the way groundwater is considered, understood and managed in many countries around the world. A prolific researcher and author, he is also a pioneer in assembling multidisciplinary teams and in approaching the study of groundwater from a holistic perspective.

Aged 85, Professor Llamas continues to be an inspiration to those around him. While his scientific production has slowed down in recent years, his research ethic remains strong and his willingness to work is as unfailing as ever. He continues to publish academic papers on a regular basis, while also organizing and attending meetings on anything related to water. He still works long hours, to the point that his colleagues have become accustomed to expect an informative or enquiring email from him at any time of the day (or night). Anyone driving past the Faculty of Geology on a Sunday evening will surely notice that the lights are on in one of the rooms on the fifth floor, which is easy to spot because all other lights in the building will most likely be turned off. That is Ramon's office.

Acknowledgements The authors would like to thank the editorial team of Hydrogeology Journal for their willing cooperation and warm regards for Prof Llamas.

\section{References}

Coleto MC, Martínez Cortina L, Llamas MR (eds) (2003) Conflictos entre el desarrollo de las aguas subterráneas y la conservación de los humedales: la cuenca alta del Guadiana [Conflicts between the development of groundwater and wetland conservation: the upper basin of the Guadiana]. Fundación Botín and Ediciones Mundiprensa, Madrid, $352 \mathrm{pp}$

Custodio E, Llamas MR (1976) Hidrología subterránea [Groundwater hydrogeology], 2 vols. Omega, 2418 pp. http:// www. ommegaonline.org/. October 2016

Custodio E, Llamas MR, Villarroya F (1998) The role of the Spanish Committee of the International Association of Hydrogeologists in the management and protection of Spain's groundwater resources. Hydrogeol J 6:15-23

De Stefano L, Llamas MR (eds) (2013) Water, agriculture and the environment in Spain: can we square the circle? Fundación Botín, Madrid; CRC, London, 316 pp

Garrido A, Llamas MR, Varela-Ortega C, Novo P, Rodríguez-Casado R, Aldaya MM (2010) Water footprint and virtual water trade in Spain: policy implications. Springer, New York, 153 pp

Llamas MR, Custodio E (eds) (2003) Intensive use of groundwater: challenges and opportunities. Balkema, Dordrecht, The Netherlands, $484 \mathrm{pp}$

Llamas MR, Martínez-Santos P (2005) Intensive groundwater use: silent revolution and potential source of social conflict. ASCE J Water Resour Plan Manag 131(5):337-341

Llamas MR, Fornés JM, Hernández-Mora N, Martínez-Cortina L (2001) Aguas subterráneas: retos y oportunidades [Groundwater: challenges and opportunities]. Fundación Botín and Ediciones MundiPrensa, Madrid, 529 pp

Llamas MR, Martinez-Santos P, De la Hera A (2006a) The manifold dimensions of groundwater sustainability: an overview. In: Ragone S, la Hera D, Hernandez-Mora N (eds) Proceedings of the international symposium on groundwater sustainability. National Ground Water Association Press, Westerville, OH, pp 105-116

Llamas RM, Mukherji A, Shah T (2006b) Guest editors' preface. (Special issue: Social and economic aspects of groundwater governance). Hydrogeol J 14:269-274 
Llamas MR, Martínez-Cortina L, Mukherji A (eds) (2009) Water ethics. Taylor \& Francis, London, 353 pp

Martínez-Cortina L, Garrido A, Lopez-Gunn E (eds) (2010) Re-thinking water and food security. CRC, Boca Raton, FL, 400 pp

Martínez-Santos P, Aldaya MM, Llamas MR (eds) (2014) Integrated water resources management in the 21st century: revisiting the paradigm. CRC, London, $302 \mathrm{pp}$

Rogers PP, Llamas MR, Martínez-Cortina L (eds) (2006) Water crisis: myth or reality? Taylor \& Francis, London, 331 pp
Struckmeier W, Howard K, John Chilton J (2016) The International Association of Hydrogeologists (IAH): reflecting on 60 years of contributions to groundwater science and water management. Hydrogeol J 24:1069-1086

Willaarts B, Garrido A, Llamas MR (eds) (2014) Water for food security and well-being in Latin America and the Caribbean: social and environmental implications for a globalized economy. Routledge, New York, $432 \mathrm{pp}$ 